\title{
Gram-negative intestinal indigenous microbiota from two Siluriform fishes in a tropical reservoir
}

\author{
Silvana Duarte ${ }^{1}$, Flávia Cristina de Paula e Silva ${ }^{2}$, Danielle Alves Gomes Zauli ${ }^{2}$, \\ Jacques Robert Nicoli ${ }^{2}$, Francisco Gerson Araújo ${ }^{1 *}$ \\ ${ }^{1}$ Laboratório de Ecologia de Peixes, Universidade Federal Rural do Rio de Janeiro, Seropédica, \\ RJ, Brazil. \\ ${ }^{2}$ Departamento de Microbiologia, Instituto de Ciências Biológicas, \\ Universidade Federal de Minas Gerais, Belo Horizonte, MG, Brazil.
}

Submitted: October 15, 2013; Approved: April 17, 2014.

\begin{abstract}
The Gram-negative intestinal microbiota of Hypostomus auroguttatus and Pimelodus maculatus, a detritivorous and an omnivorous fish species, respectively, were compared between fishes from the reservoir and the stretch of the river below the dam of the Funil hydroelectric plant, Rio de Janeiro, Brazil. Four selective culture media were used under aerobic and two under anaerobic conditions. The omnivorous species had microbiota with higher population levels compared to the detritivorous species. The number of morphotypes and population levels of total bacteria, vibrio and Bacteroides tended to be higher in summer and autumn in the reservoir, and not different in the river. The number of morphotypes of enterobacteria and total bacteria were higher in the lotic environment compared with the lentic one. The bacteria Aeromonas hydrophila and Plesiomonas shigelloides and the obligate anaerobic Fusobacterium mortiferum were the most frequently identified microorganisms in the intestine of both $H$. auroguttatus and P. maculatus. Both season and habitat influenced the Gramnegative intestinal microbiota of $H$. auroguttatus and $P$. maculatus. Environmental factors influenced the Gram-negative intestinal microbiota of both species with possible impact on the interrelationship between the fishes and their digestive ecosystem, although the gut microbiota composition of fishes may result from host-specific selective pressures within the gut.
\end{abstract}

Key words: alimentary regimen, environment, gut microbiology, Hypostomus auroguttatus, Pimelodus maculatus.

\section{Introduction}

The gastrointestinal microbiota of fish consists of similar population levels of strict and facultative anaerobes that, similarly to other animal species, have three main functions: resistance to colonization by pathogens, modulation of the immune system and nutritional contribution for the host (Búcio et. al., 2006). In this sense, an optimization of the relationship between the host with its associated microbiota is fundamental for the preservation and maximal exploitation of the microbiota and its mentioned functions. Therefore, a thorough knowledge of the identity of the components of this microbiota as well as the mechanisms they use to carry out their functions are required.

The composition of the microbiota and its functions may change or be influenced by factors such as diet and environmental conditions (Ringo et al., 2001). Currently, a high amount of information about environmental influences on gut microbiota associated with human and some domestic (pigs and poultry) and laboratory (rats and mice) terrestrial animals is available (Ley, 2008, Bevins and Salzman, 2011) but less is known for aquatic animal species. Concerning fishes, there is also little information on the factors (nutritional, environmental and stress) that may in- 
fluence the equilibrium population of the normal microbiota and consequently their functions.

The degree of contribution of the indigenous microbiota to the digestive physiology of their host depends on the diet, and also on the complexity and difficulty to use the nutrient ingested by the host. In this way, herbivorous and detritivorous fishes depend much more on their microbiota than omnivorous and carnivorous fishes (Prejs and Blaszczyk, 2006; Shangong et al., 2010). The need for microbial contribution is accompanied by the existence of a longer, more complex and compartmented gastrointestinal tract (fermentation chamber), generally developed during the co-evolutionary development process between the host and its microbiota (Seeto et al., 1996).

Although there is a reasonable amount of information on the influence of feeding habits on the intestinal microbial populations, little is known on the habitat influences (e.g., lotic vs. lentic) and seasonal changes. Most ecological and physiological processes are supposed to change according to these constraints, including the intestinal microbiota (Podkowa and Goniakowska-Witalinska, 2003). In a lentic system (reservoir), the environmental variables tend to change in a wider scale when compared to the more stable environmental conditions of a lotic system (river) (Soares et al., 2008). Moreover, most of the lentic systems tend to eutrophication as they become old and receive and accumulate organic loads. In contrast, the continuous and unidirectional water movement of a lotic system enables more stable environmental conditions and generally leads to better water quality due to its constant renovation (Klapper, 1998). Similarly, seasonality should also influence microorganisms in the environment and in the indigenous microbiota of fish, in particular because the effect of rainwater as a nutrient carrier. Finally, physical, chemical, and nutritional changes found in different ecological environments are expected to affect the type and population levels of microorganisms.

The armored catfish (Hypostomus auroguttatus, Kner 1854) is a benthic iliophagous/herbivorous species with ventral lips (oral papillae) adhering to the river bottom and feeding by grasping the plant organic matter and "microalgae film" associated to rocky substrate (Fugi and Hahn, 1991). Such characteristics are probably functionally related to the fact that individuals in this species have one of the largest intestines among the teleosteans, with some individuals of this species having intestines reaching about fifteen times their individual length (Duarte et al., 2013). This suggests the occurrence of a prolonged digestive process (Nelson, 2002) that might depend on the presence of microbiota.

The long-whiskered catfish (Pimelodus maculatus, Lacepède 1803) is also a benthic species, capable to perform limited reproductive seasonal migration to spawn (Dei Tos et al., 2002). It is an omnivorous species with tendency to carnivorous regimen, having an intestinal size of almost 1.5 times its total length (Lobón-Cerviá and Bennemann, 2000). Vaz et al. (2000) reported that $P$. maculatus feeds on larvae of benthonic insects, algae, mollusks, fish, and plant fragments, accumulating reserves to be used in gonad development along the maturation process during the summer.

In the present study, the influence of feeding habits (iliophagous/detritivorous vs. omnivorous), habitat (lentic vs. lotic) and seasonality on the number of morphotypes and the population levels of the Gram-negative digestive microbiota of two siluriform fishes $(H$. auroguttatus and $P$. maculatus) was evaluated. By examining such differences in gut bacteria of fish from different trophic levels, seasons and habitats, we investigated some factors that shape these communities. We expected that fish with different diets, especially those that are difficult to digest (as the case of $H$. auroguttatus), have been selected to harbour more bacterial communities with more number of morphotypes and population levels. We also expected, a priori, that those indicators of microbes community would differ among seasons and between the more stable lotic habitat and the more changeable conditions of the lentic habitat.

\section{Materials and Methods}

\section{Study area}

Built in 1969, the reservoir of the Funil hydroelectric plant $\left(22^{\circ} 30^{\prime} \mathrm{S}, 44^{\circ} 45^{\prime} \mathrm{W}\right.$, altitude $440 \mathrm{~m}$ ) is located in the middle section of the basin of the Paraíba do Sul river, within the Atlantic Forest biome of Southeastern Brazil (Figure 1). This reservoir is the largest artificial impoundment in the river, with an area of $40 \mathrm{~km}^{2}$, maximum depth of $70 \mathrm{~m}$, and water retention time of 10-50 days (Carvalho and Torres, 2002).

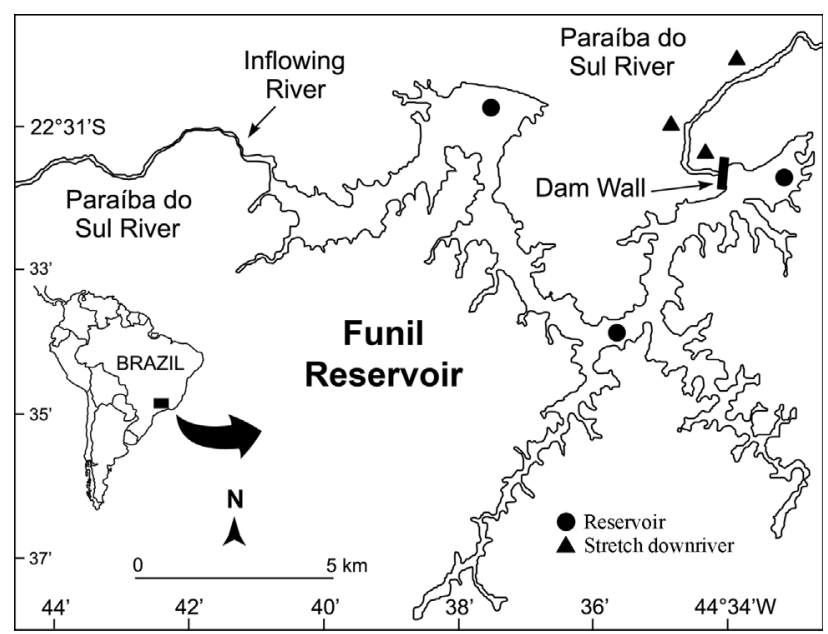

Figure 1 - Study area, Funil reservoir and the main inflowing river (Paraíba do Sul river), with indications of the sampling sites in the reservoir and in the stretch downriver of the reservoir. 
The Paraíba do Sul river (PSR) basin drains a major industrialized area in Brazil and suffers several impacts along its extension, with the heaviest alteration occurring in the middle reaches, where a generalized pollution from organic and industrial effluents is observed due to poorly planned sewage municipal systems. The climate is subtropical with monthly mean water temperatures of $18-24{ }^{\circ} \mathrm{C}$. Rainfall volume is higher in the summer months (December-January, 200-250 mm per month) and lower in the winter months (June-August, $<50 \mathrm{~mm}$ per month).

Funil reservoir has poor water quality. It receives large amounts of phosphorus during the increases inflow of the Paraiba do Sul river. Dissolved oxygen, $\mathrm{pH}$, and chlorophyll a levels peaked in the wet season; $\mathrm{pH}$, chlorophyll a, and total phosphorus in several cases were recorded above the recommended Brazilian guidelines (Branco et al., 2002). Dissolved oxygen was lower than acceptable levels in the euphotic layer and reached very low levels in the hypolimnion, indicating thermal stratification (Araújo et al., 2011). Ferrão-Filho et al. (2009) showed that the high input of $\mathrm{N}$ and $\mathrm{P}$ favored the persistent dominance of cyanobacteria; cyanobacteria included potential hepatotoxins (microcystins) producers like Microcystis spp., and potential neurotoxins (saxitoxins) producers like Anabaena circinalis and Cylindrospermopsis raciborskii. Funil Reservoir is a turbid (median euphotic zone $=4.3 \mathrm{~m}$ ), eutrophic reservoir (median total phosphorus $=3.1 \mu \mathrm{M}$ ), with a high phytoplankton biomass (median chlorophyll-a concentration $\left.=10.0 \mu \mathrm{g} \mathrm{L}^{-1}\right)($ Branco et al., 2008).

\section{Fish collection and sample handling}

The fishes were collected from two habitats: the Funil reservoir (lentic habitat) and the stretch of the Paraíba do Sul downriver of the Funil dam (lotic habitat). Thirty adult individuals of $H$. auroguttatus averaging $242 \pm 4.5 \mathrm{~mm}$ total length (TL) and $152 \pm 11.6 \mathrm{~g}$ total weight (TW), and 28 adults of $P$. maculatus averaging $252 \pm 5.4 \mathrm{~mm}$ TL and $184 \pm 13.1 \mathrm{~g}$ TW were collected. Fish collection occurred in July (winter) and October (spring) 2003, and in January (summer) and April (autumn) 2004. Four sets of three gill nets (30 m long x $2.5 \mathrm{~m}$ height) with different mesh sizes $(2.5,4.5$ and $6.5 \mathrm{~cm}$ stretched knots) were used to sample an area of ca. $900 \mathrm{~m}^{2}$. The nets were deployed near to the shoreline during the afternoon and retrieved in the following morning, fishing for approximately $15 \mathrm{~h}$. Voucher specimens were deposited in the Fish Collection of the Laboratory of Fish Ecology, University Federal Rural of Rio de Janeiro, under numbers LEP-UFRRJ 996 and 997, for H. auroguttatus, and 998 and 999, for P. maculatus.

The specimens were transported alive to the laboratory and sacrificed by immersion in water at $4{ }^{\circ} \mathrm{C}$ associated with an anterior incision to remove their intestines in a laminar flow hood (Vecco, Campinas, Brazil). The contents from the distal portion of the intestine were weighed and immediately introduced into an anaerobic chamber (Forma Scientific Company, Marietta, U.S.A.) containing an atmosphere of $85 \% \mathrm{~N}_{2}, 10 \% \mathrm{H}_{2}$ and $5 \% \mathrm{CO}_{2}$. Then, the intestinal contents were submitted to serial decimal dilutions from $10^{-2}$ to $10^{-9}$ in sterile saline, and a volume of $0.1 \mathrm{~mL}$ of each dilution was plated onto Petri dishes containing the following selective and universal culture media: blood agar supplemented with $0.5 \%$ yeast extract, $0.1 \%$ hemin and $0.1 \%$ menadione, and Bacteroides Bile Esculin (BBE) agar. Sequentially, the same dilutions were removed from the anaerobic chamber and a volume of $0.1 \mathrm{~mL}$ of each of them used to inoculate under aerobic conditions Petri dishes containing: blood agar; MacConkey agar (Difco, Sparks, U.S.A.); thiosulfate citrate bile sucrose (TCBS) agar (Oxoid, Basingstoke, U.K.); and YM agar. After incubation at $25^{\circ} \mathrm{C}$ for $24-48 \mathrm{~h}$ and 7 days under aerobic and anaerobic conditions, respectively, determination of colony counts and number of different morphotypes as well as isolation of dominant microorganisms of the intestinal contents were performed using the appropriate dilution. Population levels were expressed as decimal logarithm of colony forming units per gram of contents $\left(\log _{10} \mathrm{cfu} \mathrm{g}^{-1}\right)$.

For isolation, a sample of each different colony morphotype was inoculated in the same original culture medium and an aliquot submitted to microscopic observations after Gram staining. Each isolate was also submitted to a determination of the growth atmosphere (facultative anaerobe, obligate anaerobe, or microaerophilic). The definitive identification was completed with the results obtained from the following API identification kits (BioMérieux SA, Marcy-l'Étoile, France): 20 A for obligate anaerobes, $20 \mathrm{E}$ for enterobacteria and other Gram-negative bacteria, and 20 AUX for yeasts. When necessary, supplementary biochemical or physiological tests were performed (catalase, indol, $\mathrm{H}_{2} \mathrm{~S}$ production, esculin hydrolysis and carbohydrate fermentation).

Statistical significance of the results was evaluated by non-parametric Kruskal-Wallis and Mann-Whitney tests for comparing multiple independent samples among groups. The level of significance was set at $p<0.05$. Statistical analyses were performed using the Statistic software v.7.1 (StatSoft, Inc., USA).

\section{Results}

\section{Feeding habits}

The number of morphotypes did not differ between the two fish species, with exception for the vibrio group that was significantly higher $(\mathrm{H}=9.2, \mathrm{p}<0.05)$ for P. maculatus when compared to H. auroguttatus (Table 1). The highest number of morphotypes was noted for the enterobacteria group with a number of about $4(3.9 \pm 2.0)$ and 5 (4.7 \pm 2.9$)$ per fish for $P$. maculatus and H. auroguttatus, respectively. 
Table 1 - Number of morphotypes ( \pm SD) and population levels $\left(\log _{10}\right.$ cfu $^{-1}$ of contents \pm SD) of bacterial groups in the digestive microbiota of Pimelodus maculatus and Hypostomus auroguttatus.

\begin{tabular}{|c|c|c|c|c|}
\hline \multirow[t]{2}{*}{ Bacterial group } & \multicolumn{2}{|c|}{ Morphotypes } & \multicolumn{2}{|c|}{ Population levels } \\
\hline & Pimelodus maculatus & Hypostomus auroguttatus & Pimelodus maculatus & Hypostomus auroguttatus \\
\hline Total anaerobes & $3.7 \pm 1.7$ & $4.5 \pm 1.7$ & $7.9 \pm 0.8$ & $6.2 \pm 1.2^{*}$ \\
\hline Bacteroides & $1.9 \pm 0.8$ & $1.9 \pm 1.2$ & $7.5 \pm 1.1$ & $4.8 \pm 2.3 *$ \\
\hline Total aerobes & $2.2 \pm 1.5$ & $2.5 \pm 2.0$ & $6.3 \pm 3.2$ & $4.7 \pm 2.9^{*}$ \\
\hline Enterobacteria & $3.9 \pm 2.0$ & $4.7 \pm 2.9$ & $7.2 \pm 1.7$ & $5.7 \pm 1.7 *$ \\
\hline Vibrio & $2.1 \pm 1.4$ & $1.0 \pm 1.4^{*}$ & $5.0 \pm 2.6$ & $3.0 \pm 2.8^{*}$ \\
\hline
\end{tabular}

*Significant difference between Hypostomus auroguttatus and Pimelodus maculatus (Kruskal-Wallis, $\mathrm{p}<0.05$ ).

Supplemented blood agar: total anaerobes; BBE agar: Bacteroides; Blood agar: total aerobes; MacConkey agar: enterobacteria; TCBS agar: Vibrio.

On the other hand, population levels differed significantly between the two species for all bacterial groups, with significantly higher values for $P$. maculatus when compared to $H$. auroguttatus $(\mathrm{p}<0.05)$. As expected for aquatic species, Gram-negative facultative anaerobes (enterobacteria group) represented the dominant populations in the intestines of both fishes with $7.2 \pm 1.7$ and $5.7 \pm 1.7 \log _{10} \mathrm{cfu} \mathrm{g}^{-1}$ of contents for $P$. maculatus and $H$. auroguttatus, respectively.

\section{Seasons}

Seasonal differences were found only for the number of morphotypes for $H$. auroguttatus in the reservoir (Table 2), with a trend for higher values in summer for total aerobes, vibrio $(\mathrm{H}=8.0, \mathrm{p}=0.04)$ and Bacteroides $(\mathrm{H}=8.0$, $\mathrm{p}=0.04)$ and in spring and autumn for total anaerobes $(\mathrm{H}=10, \mathrm{p}=0.01)$ when compared with the other seasons. Population levels also differed only for the reservoir (Table 3), with higher values in summer for vibrio and total aerobes $(\mathrm{H}=7.6, \mathrm{p}=0.05)$, and in summer and autumn for
Bacteroides $(\mathrm{H}=9.6, \mathrm{p}=0.02)$ when compared to other seasons.

No seasonal difference (Table 4) was found for the number of morphotypes for $P$. maculatus, except for vibrio $(\mathrm{H}=8.0, \mathrm{p}=0.04)$ obtained from individuals collected in the reservoir, with significant higher values in summer when compared to other seasons. Population levels changed seasonally (Table 5), with higher values for enterobacteria $(\mathrm{H}=8.4, \mathrm{p}=0.03)$ of fishes collected in the reservoir in winter when compared to the spring. For the river, comparatively higher values were observed for winter and spring when compared to summer and autumn for total anaerobes $(\mathrm{H}=10.9, \mathrm{p}=0.01)$ and Bacteroides $(\mathrm{H}=10.5, \mathrm{p}=0.01)$.

\section{Habitats (lotic vs. lentic)}

The number of morphotypes was significantly higher for $H$. auroguttatus from the river when compared to the reservoir only for enterobacteria (Table 2). On the other hand, no significant difference was found between the two systems for population levels of any of the bacterial groups (Table 3).

Table 2 - Number of morphotypes ( \pm SD) of bacterial groups in the digestive microbiota of Hypostomus auroguttatus from lentic (Res) and lotic (Riv) habitats and seasons.

\begin{tabular}{|c|c|c|c|c|c|}
\hline Bacterial group & & Spring & Summer & Autumn & Winter \\
\hline \multirow[t]{2}{*}{ Total anaerobes } & Res & $5.3 \pm 1.5^{\mathrm{a}}$ & $3.8 \pm 1.2^{\mathrm{ab}}$ & $5.0 \pm 1.2^{\mathrm{a}}$ & $2.5 \pm 1.0^{\mathrm{b}}$ \\
\hline & Riv & $6.2 \pm 1.3$ & $4.0 \pm 0.0^{\mathrm{a}}$ & $4.0 \pm 0.0$ & $4.0 \pm 0.0$ \\
\hline \multirow[t]{2}{*}{ Bacteroides } & Res & $0.5 \pm 0.6^{\mathrm{a}}$ & $2.5 \pm 0.6^{\mathrm{b}}$ & $2.4 \pm 0.9^{\mathrm{b}}$ & $1.3 \pm 1.5^{\mathrm{ab}}$ \\
\hline & Riv & $2.0 \pm 1.4$ & $2.0 \pm 0.0$ & $2.0 \pm 0.0$ & $3.5 \pm 0.7$ \\
\hline \multirow[t]{2}{*}{ Total aerobes } & Res & $1.8 \pm 3.5^{\mathrm{a}}$ & $4.3 \pm 0.5^{\mathrm{b}}$ & $2.4 \pm 0.9^{\mathrm{ab}}$ & $2.0 \pm 1.1^{\mathrm{a}}$ \\
\hline & Riv & $0.0 \pm 0.0$ & $3.5 \pm 2.1$ & $3.0 \pm 0.0$ & $3.0 \pm 4.2$ \\
\hline \multirow[t]{2}{*}{ Enterobacteria } & Res & $4.3 \pm 1.0$ & $3.8 \pm 2.1$ & $3.2 \pm 1.1$ & $3.3 \pm 3.9$ \\
\hline & Riv & $6.9 \pm 2.6$ & $3.5 \pm 2.1$ & $4.0 \pm 1.0$ & $9.0 \pm 4.2$ \\
\hline \multirow[t]{2}{*}{ Vibrio } & Res & $0.0 \pm 0.0^{\mathrm{a}}$ & $3.0 \pm 2.7^{\mathrm{b}}$ & $1.2 \pm 1.0^{\mathrm{ab}}$ & $0.8 \pm 1.3^{\mathrm{ab}}$ \\
\hline & Riv & $0.6 \pm 0.5$ & $1.5 \pm 0.7$ & $1.0 \pm 0.0$ & $0.5 \pm 0.7$ \\
\hline
\end{tabular}

Different letters indicate significant difference between the seasons (Mann-Whitney non parametric test, $\mathrm{p}<0.05$ ).

Supplemented blood agar: total anaerobes; BBE agar: Bacteroides; Blood agar: total aerobes; MacConkey agar: enterobacteria; TCBS agar: Vibrio. 
Table 3 - Population levels ( $\log _{10} \mathrm{cfu} \mathrm{g}^{-1}$ of contents $\pm \mathrm{SD}$ ) of bacterial groups in the digestive microbiota of Hypostomus auroguttatus from lentic (Res) and lotic (Riv) habitats and seasons.

\begin{tabular}{|c|c|c|c|c|c|}
\hline Bacterial group & & Spring & Summer & Autumn & Winter \\
\hline \multirow[t]{2}{*}{ Total anaerobes } & Res & $5.8 \pm 0.5$ & $6.4 \pm 1.8$ & $6.2 \pm 1.4$ & $5.7 \pm 1.9$ \\
\hline & Riv & $6.6 \pm 0.6$ & $6.4 \pm 1.8$ & $6.5 \pm 0.0$ & $6.2 \pm 0.4$ \\
\hline \multirow[t]{2}{*}{ Bacteroides } & Res & $2.3 \pm 2.7^{\mathrm{a}}$ & $6.4 \pm 0.5^{\mathrm{b}}$ & $6.2 \pm 1.5^{\mathrm{b}}$ & $3.5 \pm 2.8^{\mathrm{a}}$ \\
\hline & Riv & $5.1 \pm 1.5$ & $5.4 \pm 2.0$ & $5.7 \pm 0.0$ & $5.4 \pm 0.0$ \\
\hline \multirow[t]{2}{*}{ Total aerobes } & Res & $1.5 \pm 3.0^{\mathrm{a}}$ & $6.9 \pm 0.6^{\mathrm{b}}$ & $6.4 \pm 0.8^{\mathrm{ab}}$ & $5.5 \pm 1.9^{\mathrm{ab}}$ \\
\hline & Riv & $0.0 \pm 0.0$ & $6.1 \pm 2.3$ & $6.6 \pm 0.0$ & $2.8 \pm 4.0$ \\
\hline \multirow[t]{2}{*}{ Enterobacteria } & Res & $5.6 \pm 0.4$ & $5.9 \pm 0.7$ & $6.5 \pm 0.9$ & $4.2 \pm 3.3$ \\
\hline & Riv & $6.2 \pm 0.5$ & $5.5 \pm 1.5$ & $6.2 \pm 0.0$ & $5.7 \pm 0.6$ \\
\hline \multirow[t]{2}{*}{ Vibrio } & Res & $0.0 \pm 0.0^{\mathrm{a}}$ & $5.7 \pm 1.0^{\mathrm{c}}$ & $2.8 \pm 1.9^{\mathrm{bc}}$ & $2.3 \pm 3.5^{\mathrm{b}}$ \\
\hline & Riv & $2.9 \pm 2.8$ & $5.5 \pm 1.5$ & $5.3 \pm 0.0$ & $2.7 \pm 3.7$ \\
\hline
\end{tabular}

Different letters indicate significant difference between the seasons (Mann-Whitney non parametric test, $\mathrm{p}<0.05$ ).

Supplemented blood agar: total anaerobes; BBE agar: Bacteroides; Blood agar: total aerobes; MacConkey agar: enterobacteria; TCBS agar: Vibrio.

Table 4 - Number of morphotypes ( \pm SD) of bacterial groups in the digestive microbiota of Pimelodus maculatus from lentic (Res) and lotic (Riv) habitats and seasons.

\begin{tabular}{llllll}
\hline Bacterial group & & Spring & Summer & Autumn & Winter \\
\hline Total anaerobes & Res & $3.3 \pm 2.8$ & $3.7 \pm 1.5$ & $2.0 \pm 0.0$ & $3.8 \pm 2.2$ \\
Bacteroides & Riv & $4.6 \pm 0.5$ & $4.0 \pm 1.0$ & $3.2 \pm 1.6$ & $4.3 \pm 0.6$ \\
& Res & $1.5 \pm 1.4$ & $2.0 \pm 0.0$ & $1.0 \pm 0.0$ & $1.8 \pm 0.8$ \\
\hline Total aerobes & Riv & $2.2 \pm 0.4$ & $2.3 \pm 0.6$ & $1.8 \pm 0.4$ & $2.0 \pm 0.0$ \\
& Res & $2.0 \pm 2.3$ & $2.5 \pm 1.0$ & $4.0 \pm 1.1$ & $1.6 \pm 1.1$ \\
Enterobacteria & Riv & $1.2 \pm 1.1$ & $2.7 \pm 1.5$ & $3.4 \pm 1.3$ & $2.0 \pm 0.0$ \\
& Res & $4.3 \pm 2.3$ & $4.0 \pm 1.7$ & $5.0 \pm 0.0$ & $3.4 \pm 1.1$ \\
Vibrio & Riv & $2.8 \pm 2.3$ & $6.0 \pm 1.7$ & $3.2 \pm 1.6$ & $4.7 \pm 2.5$ \\
& Res & $0.0 \pm 0.0^{\mathrm{c}}$ & $3.0 \pm 2.7^{\mathrm{a}}$ & $1.2 \pm 1.1^{\mathrm{b}}$ & $0.8 \pm 1.3^{\mathrm{b}}$ \\
\hline
\end{tabular}

Different letters indicate significant difference between the seasons (Mann-Whitney non parametric test, $\mathrm{p}<0.05$ ).

Supplemented blood agar: total anaerobes; BBE agar: Bacteroides; Blood agar: total aerobes; MacConkey agar: enterobacteria; TCBS agar: Vibrio.

Table 5 - Population levels ( $\log _{10}$ cfu g ${ }^{-1}$ of contents $\pm \mathrm{SD}$ ) of bacterial groups in the digestive microbiota of Pimelodus maculatus from lentic (Res) and lotic (Riv) habitats and seasons.

\begin{tabular}{llcccc}
\hline Bacterial group & & Spring & Summer & Autumn & Winter \\
\hline Total anaerobes & Res & $7.2 \pm 1.5$ & $7.4 \pm 0.0$ & $7.5 \pm 0.0$ & $8.2 \pm 0.5$ \\
Bacteroides & Riv & $8.5 \pm 0.3^{\mathrm{a}}$ & $7.7 \pm 0.4^{\mathrm{b}}$ & $7.6 \pm 0.3^{\mathrm{b}}$ & $8.4 \pm 0.3^{\mathrm{a}}$ \\
& Res & $6.7 \pm 1.8$ & $7.9 \pm 0.3$ & $7.5 \pm 0.0$ & $6.8 \pm 1.3$ \\
\hline Total aerobes & Riv & $8.2 \pm 0.3^{\mathrm{a}}$ & $7.3 \pm 0.2^{\mathrm{b}}$ & $7.4 \pm 0.5^{\mathrm{b}}$ & $8.2 \pm 0.3^{\mathrm{a}}$ \\
& Res & $3.6 \pm 4.1$ & $7.8 \pm 0.3$ & $8.1 \pm 0.0$ & $5.7 \pm 3.4$ \\
Enterobacteria & Riv & $5.2 \pm 4.7$ & $7.7 \pm 0.3$ & $7.8 \pm 0.3$ & $8.0 \pm 0.1$ \\
& Res & $6.0 \pm 1.1^{\mathrm{a}}$ & $7.2 \pm 0.6^{\mathrm{ab}}$ & $7.7 \pm 0.0^{\mathrm{ab}}$ & $7.6 \pm 0.6^{\mathrm{b}}$ \\
Vibrio & Riv & $6.8 \pm 4.0$ & $7.4 \pm 0.2$ & $7.8 \pm 0.4$ & $7.8 \pm 0.2$ \\
& Res & $0.0 \pm 0.0$ & $5.7 \pm 1.0$ & $2.9 \pm 1.9$ & $2.3 \pm 3.5$ \\
\hline
\end{tabular}

Different letters indicate significant difference between the seasons (Mann-Whitney non parametric test, $\mathrm{p}<0.05$ ).

Supplemented blood agar: total anaerobes; BBE agar: Bacteroides; Blood agar: total aerobes; MacConkey agar: enterobacteria; TCBS agar: Vibrio. 
For P. maculatus, no significant differences in the number of morphotypes was found between the bacterial groups (Table 4), while the population level was significantly higher for the river compared with the reservoir for the vibrio group (Table 5).

\section{Growth atmosphere requirements}

The mean number of morphotypes of total aerobes was similar for both fish species and both habitats, ranging from $0.0 \pm 0.0$ in the river during spring to $4.3 \pm 0.5$ in the reservoir during summer for $H$. auroguttatus, and from 1.2 \pm 1.1 in the river during spring to $4.0 \pm 1.1$ in the reservoir during autumn for P. maculatus (Tables 1, 2 and 4). The mean population levels of total aerobes for $H$. auroguttatus $(4.7 \pm 2.9)$ was significantly lower than for $P$. maculatus $\left(6.3 \pm 3.2 \log _{10} \mathrm{cfu} \mathrm{g}^{-1}\right.$; Table 1$)$. There is a slight trend for higher values in the reservoir compared with the river for $H$. auroguttatus, whereas no difference in habitats were found for P. maculatus (Tables 1, 3 and 5).

In relation to the mean number of morphotypes for total anaerobes, the values were similar for both fish species and habitats, ranging from $2.5 \pm 1.0$ in the reservoir during winter to $6.2 \pm 1.3$ in the river during spring for $H$. auroguttatus, and from $2.0 \pm 0.0$ in the reservoir during autumn to $4.6 \pm 0.5$ in the river during spring for P. maculatus (Tables 1, 2 and 4). The mean population levels of total anaerobes for $H$. auroguttatus was significantly lower compared with $P$. maculatus, with no differences between the habitats for $H$. auroguttatus, and a slight trend for higher values in the river for $P$. maculatus (Tables 1, 4 and 5). Mean values ranged from $5.7 \pm 1.9 \log _{10} \mathrm{cfu} \mathrm{g}^{-1}$ in the reservoir during winter to $6.6 \pm 0.6 \log _{10} \mathrm{cfu} \mathrm{g}^{-1}$ in the river during spring for $H$. auroguttatus, and from $7.2 \pm 1.5 \log 10 \mathrm{cfu}$ g- 1 in the reservoir during spring to $8.5 \pm 0.3 \log _{10} \mathrm{cfu}^{-1}$ in the river during spring for $P$. maculatus (Tables 3 and 5).

\section{Bacterial species}

A list of identified bacteria for each species in both habitats is shown in Table 6. All the bacteria were Gramnegative bacteria rods, and most of them were facultative anaerobes. The most frequent bacteria were the facultative anaerobe Plesiomonas shigelloides and Aeromonas hydrophila and the obligate aerobe Fusobacterium mortiferum for both fish species, independently of the habitat. A higher biodiversity of bacterial species was observed for H. auroguttatus in the reservoir and for P. maculatus in the river.

\section{Discussion}

\section{Feeding habits}

The gastrointestinal microbiota in fishes is essentially constituted of Gram-negative facultative and obligate anae-
Table 6 - Facultative and obligate anaerobic bacteria identified in the gut of Hypostomus auroguttatus and Pimelodus maculatus from lentic (Res) and lotic (Riv) habitats.

\begin{tabular}{|c|c|c|c|c|}
\hline \multirow[t]{2}{*}{ Bacterial species } & \multicolumn{2}{|c|}{$\begin{array}{l}\text { Hypostomus } \\
\text { auroguttatus }\end{array}$} & \multicolumn{2}{|c|}{$\begin{array}{l}\text { Pimelodus } \\
\text { maculatus }\end{array}$} \\
\hline & Res & Riv & Res & Riv \\
\hline Pantoea spp. & $\mathrm{X}$ & & & \\
\hline Photobacterium damsella & $\mathrm{X}$ & & & \\
\hline Pseudomonas aeruginosa & $\mathrm{X}$ & & & \\
\hline Edwardsiella tarda & $\mathrm{X}$ & & $\mathrm{X}$ & $\mathrm{X}$ \\
\hline Pasteurella pneumoniae & $\mathrm{X}$ & & & $\mathrm{X}$ \\
\hline Enterobacter sakazakii & $\mathrm{X}$ & & & \\
\hline Edwarsiella tarda & $\mathrm{X}$ & & & \\
\hline Serratia odorifera & $\mathrm{X}$ & & & $\mathrm{X}$ \\
\hline Pseudomonas fluorescens & $\mathrm{X}$ & & & \\
\hline Plesiomonas shigelloides & $\mathrm{X}$ & & $\mathrm{X}$ & $\mathrm{X}$ \\
\hline Aeromonas hydrophila & $\mathrm{X}$ & $\mathrm{X}$ & $\mathrm{X}$ & $\mathrm{X}$ \\
\hline Enterobacter cloacae & & $\mathrm{X}$ & $\mathrm{X}$ & \\
\hline Citrobacter freundii & & & & $\mathrm{X}$ \\
\hline Morganella morganii & & & & $\mathrm{X}$ \\
\hline Bordetella alcaligenes & & & & $\mathrm{X}$ \\
\hline Non fermenting bacterium & & & $\mathrm{X}$ & \\
\hline Fusobacterium mortiferum & $\mathrm{X}$ & $\mathrm{X}$ & $\mathrm{X}$ & $\mathrm{X}$ \\
\hline
\end{tabular}

robes, which may vary among fish species with different digestive apparatus (Sullan et al., 2012). Microorganisms are known to play crucial roles in maintaining gut integrity, in strengthening immunity and disease resistance, and in contributing to digestion in higher animals. One of the most important issues in microbial ecology of the gastrointestinal tract is the understanding of how microorganisms may provide exogenous enzymes and fermentation products to fish with various feeding habits, especially when their diet is rich in fibers (Zhao, 2012). Symbiotic bacteria often help their hosts acquire nutrients from their diet, showing trends of co-evolution and independent acquisition by hosts from the same trophic levels. Sullam et al. (2012) revealed that trophic level and possibly host phylogeny shape the composition of fish gut bacteria. Since microbes can play an important role in digestive processes, we expected that fish with similar diets, especially those that are nutrient poor or difficult to digest, have been selected to harbour similar bacterial communities with similar functional capacities.

In the present study, relative lower bacterial population levels (maximum of c. $7.9 \log _{10} \mathrm{cfu} \mathrm{g}^{-1}$ ) were found in the intestines of both fishes when compared to mammal hosts (expected to be of c. $10^{10}$ to $10^{11} \mathrm{cfu} \mathrm{g}^{-1}$ in humans, and 109 to $10^{10} \mathrm{cfu} \mathrm{g}^{-1}$ in rodents) (Ley et al., 2008). Wu et al. (2010) found a number of average aerobic and facultative anaerobic bacteria of $3.4 \times 10^{8}$ colony-forming units (cfu) $/ \mathrm{g}$ in the intestinal content of yellow catfish (Pelteobagrus fulvidraco Richardson, 1846). This might be explained by 
the faster intestinal transit in fishes than in mammals as a limiting growth factor for bacterial populations. The mean population levels of total aerobes and total anaerobes found in the gut of the iliophagous/detritivorous $H$. auroguttatus are similar to those found by Silva et al. (2005) for Prochilodus argenteus Spix and Agassiz 1829, a migratory species with seasonal reproduction. Such similarity could be due to their similar feeding habits, which are based mainly on detritus and algae. On the other hand, the omnivorous $P$. maculatus had comparatively higher population levels when compared to those species for both total anaerobes and total aerobes. These results are unexpected since it is well known that iliophagous/detritivorous animals ingest food with high amount of recalcitrant substrates, such as fibers, and require a complex and abundant microbiota to absorb these nutrients (Silva et al., 2005; Silva et al., 2010; Silva et al., 2011). Herbivorous and some omnivorous fishes utilize gut microbes to break down cellulose, the plant structural carbohydrate (Nelson, 2002). Bacteria having these cellulose activities are either maintained in the gut or regularly brought in with ingested detritus (Prejs and Blaszczyk, 2006). Therefore, it is reasonable to suppose that this latter mechanism may be used by $H$. auroguttatus to digest its food, predominantly algae and plant detritus. On the other hand, studies determining enzymatic activities in the guts of these two species showed high glucosidase activities in $H$. auroguttatus (Duarte el al., 2013). Because microorganisms (bacteria, fungi or protozoan) are the only group capable of degrading plant substrates, the relatively low bacterial population levels in the fish intestine might be compensated by a very high enzymatic activity of bacterial cells. Contrarily to the hypothesis of a nutritional contribution of the intestinal microbiota, Smith et al. (1996) found that amounts of intestinal volatile fatty acids (VFA), end products of anaerobic fermentation, did not appear to increase in species with diets containing recalcitrant substrates.

\section{Seasons}

Syvokiene and Mickenieno (1999) reported that the intestinal microbiota population level changes according to the seasons, being higher during the more intensive feeding season (e.g., summer). This can be explained by a higher availability of substrates for the multiplication of the intestinal microbiota components, leading simultaneously to an increased enzyme activity supplied by these bacteria. In the present study, a trend for higher number of morphotypes and population levels occurred for both total aerobes and anaerobes levels during the summer and autumn for $H$. auroguttatus in the reservoir only, but no seasonal difference was found for this fish species in the river. On the other hand, P. maculatus had a slight trend for higher population levels of total anaerobe populations during the winter and spring in the river only. As pointed above, higher population levels for intestinal microbiota during the summer and autumn for $H$. auroguttatus correspond to expectation of more nutrients and higher temperatures during these seasons, conditions which can benefit microbiota multiplication (Meeren et al., 2011) Such changes were observed only in the reservoir, which is probably more susceptible to such seasonal pulses than in the more resistant conditions of the lotic system. On the other hand, P. maculatus showed seasonal change restricted to population levels of total anaerobe that reached its highest value during the winter in the river. Zambonino Filho and Schulz (1999) reported that P. maculatus trigger its gonadal development between September and March, coinciding with increased temperature, with spawning peak occurring in winter, which was associated to hydrologic cycle. Thus, this increase in microbiota populations during the winter in the river for $P$. maculatus could be due to a more intense feeding, which occurs after spawning period in riverine systems. In the reservoir, such trend is less favored because of the lentic conditions.

\section{Habitats (lotic vs. lentic)}

Syvokiene and Mickenieno (1999) reported that fishes from polluted waters have an altered intestinal microbiota. In the present study, both $H$. aurogutatus and $P$. maculatus had comparatively higher microbial intestinal populations when collected in the river when compared to the reservoir. The continuous and unidirectional water movement of the lotic system enables more stable environmental conditions and generally lead to better water quality due to its constant renovation. This could favor a more favorable environment for intestinal microbiota. Organic matters dissolved or in suspension are substrate for microorganism growth, and this development can contribute to an increased microbial population in the fish intestines and in the surrounding water. On the other hand, pollution from metals and organic chlorate compounds can inhibit the growth of allochthonous and autochthonous microbes (Olafsen 2001; Shiro et al., 2006). The presence of heavy metals accumulated in the Paraiba do Sul watershed could be the cause of low levels of microbial populations found in the intestinal microbiota (Teixeira et al., 2005; Terra et al., 2010; Terra and Araújo, 2011).

\section{Bacterial species}

Sullam et al. (2012) also identified a significant association between intestinal microbiota composition and fish taxonomy. Roeselers et al. (2011) suggest that the host gut is a selective environment and observed high similarities among fish from the same order. This finding suggests specialized and potentially co-evolved associations between fish and their gut bacteria. Given the fish longer life history compared with other vertebrates, and the overlap of their gut communities with those from mammals reported by Sullan et al. (2012), those authors proposed that fish may have served as the first vertebrate hosts for many of the microbes that have come to proliferate in the guts of mam- 
mals. They also reported that this would imply that because fish were the first hosts with adaptive immune systems encountered by bacteria, and that the guts of several fish lineages served as training grounds for microbes that would eventually evolve relationships with mammals.

Bacterial composition in the intestines is generally believed to be dependent on the water in which the fish lives (Shewan, 1977), with fish from cold marine waters being dominated by Gram-negative species (Pseudomonas, Moraxella, Flavobacterium and Shewanella). While the above picture is well known fish from cold marine waters, much less is known about fishes in warm tropical waters. The first few data on tropical fish species were included in a review by Shewan (1977), which concluded that fish from warm waters carried a heavier bacterial load than fish from cold waters, and that the former had a higher count in Gram-positive species. Comparison of data sets from fish intestines and other environments revealed that fish gut microbiota compositions are often similar to those of other animals and contain relatively few free-living environmental bacteria (Wong and Rawls, 2012). Bevins and Salzman (2011) suggest that the gut microbiota composition of fishes is not a simple reflection of the micro-organisms in their local habitat but may result from host-specific selective pressures within the gut. Therefore, fish appear to have more complex relationships with their gut bacteria than previously described, and further studies are necessary to clarify this issue.

Bacterial species such $A$. hydrophila and $P$. shigelloides are frequently found in the indigenous intestinal microbiota of most fish species, but also in many other aquatic animals. Such Gram-negative facultative anaerobe species were found in P. argenteus (Silva et al., 2005). Although most of enterobacteria species and genera in fish are part of indigenous microbiota, some are considered pathogenic, such as P. shigelloides, Pantoea spp., Enterobacter sakazakii, Serratia odorifera and Edwardsiella tarda (Shangong, 2010; Silva et al., 2010). Plesiomonas shigelloides has frequently been considered a 'tropical' or 'subtropical' bacterium due to the number of isolations in the digestive tract of fishes in countries within these areas.

Overall, Gram-negative bacteria are associated to carbohydrases production (Ramirez and Dixon, 2003). A higher number of Gram-negative facultative anaerobe bacteria was found by Silva et al. (2005) for P. argenteus, which coincide with the present findings for the two Siluriformes species. Nelson et al. (1999) failed to isolate obligate anaerobe bacteria in the gut of the Loricariids Panagolus maccus Schaefer and Stewart 1993 and Liposarcus sp., and observed a high enzymatic activity due to aerobe and facultative anaerobe intestinal bacteria. Panagolus maccus is a detritivorous species that feeds on decomposed wood, requiring the contribution of an indigenous microbiota able to supply enzymes to break recalcitrant plant polymers.
This study found differences in gut microbiota among species, season and habitat type. It represents an important step in the process of looking for the finding patterns and it highlights that one cannot assume that intestinal microbiota of fish will not be sensitive to multiple environmental and evolutionary effects. Our results, therefore, not only provide some of the first insights into the intestinal microbiota of fish gut communities in the tropics, but they also illustrate their changes according these three factors. However, these results should be interpreted conservatively because we did not have replicates per species for our habitat or season comparisons and because our results on the effects of diet are based on a two-species comparison. Differences between species of different families (although in the same order) are highly expected because their distinct phylogenetic history. Moreover, differences in the intestinal microbiota between habitat and seasons contributed to add knowledge on this research field, but biological significance of these findings can only be evaluated after a more rigorous comparative analysis that takes into account phylogenetic relationships and/or includes multiple pairs of species with similar variation in diet and/or habitat type. Therefore, further studies are necessary to clarify these issues in more details.

\section{Acknowledgments}

The authors thank Alex Braz Iacone Santos for providing the map of the study area. We also thank Dr. Dirceu Marzulo Ribeiro, Paulo Sérgio Formagio, Marcos Antonio Evangelista and Maria das Neves for infrastructure support. Furnas Centrais Elétricas S/A financially supported this research by the Program of Research and Development (P \& D), process no. 016206. The Carlos Chagas Filho Research Support Foundation of the Rio de Janeiro State, FAPERJ gave sponsorship to SD and FGA. FGA and JRN are recipients of CNPq fellowship.

\section{References}

Araújo FG, Azevedo MCC, Ferreira MNL (2011) Seasonal changes and spatial variation in the water quality of a eutrophic reservoir in the water quality of a eutrophic reservoir determined by the inflowing river. Lakes Reserv Manage 27:343-354.

Bevins CL, Salzman NH (2011) The potter's wheel: the host's role in sculpting its microbiota. Cell Mol Life Sci 68:36753685.

Branco CNC, Rocha MIA, Pinto GFS, Gômara GA, De Fellipo R (2002) Limnological features of Funil reservoir (RJ, Brasil) and indicator properties of rotifers and cladocerans of the zooplancton community. Lakes Reserv Res Manage 7:87-92.

Bucio A, Hartemink R, Schrama JW, Verreth, J, Rombouts FM (2006) Presence of lactobacilli in the intestinal content of freshwater fish from a river and from a farm with a recirculation system. Food Microbiol 23:476-482. 
Carvalho CEV, Torres JPM (2002) The ecohydrology of the Paraiba do Sul river, Southeast, Brazil In: Mclaim ME (ed) The Ecohydrology of South American Rivers and Wetlands. The IAHS Series of Special Publications, Venice, pp 179-191.

Dei Tos C, Barbieri G, Agostinho AA, Gomes LC, Suzuki HI (2002) Ecology of Pimelodus maculatus (Siluriformes) in the Corumbá reservoir, Brasil. Cybium 26:275-282.

Duarte S, Paiva MAR, Lara CC, Bemquerer MP, Araújo FG (2013) Influence of season, environment and feeding habits on the enzymatic activity of peptidase and $\beta$-glucosidase in the gastrointestinal tract of two Siluriformes fishes (Teleostei). Zoologia 30(3):296-306.

Ferrão-Lima AS, Soares MC, Rocha MIA, Magalhães VF, Oliveira-Azevedo SMF (2009) Florações de cianobactérias tóxicas no reservatório de Funil dinâmica e consequências para o zooplâncton. Oecol Bras 13(2):346-365.

Fugi R, Hahn NS (1991) Espectro alimentar e relações morfológicas com o aparelho digestivo de três espécies de peixes comedores de fundo do Rio Paraná, Brasil. Rev Bras Biol 51:873-879.

Klapper H (1998) Water quality problems in reservoirs of Rio de Janeiro, Minas Gerais and São Paulo. Hydrobiology 83:93102.

Ley RE, Hamady M, Lozupone C (2008) Evolution of mammals and the gut microbes. Science 320:1647-1651.

Lobón-Cerviá J, Bennemann S (2000) Temporal trophic shifts and feeding diversity in two sympatric, neotropical, omnivorous fishes: Astyanax bimaculatus and Pimelodus maculatus in Rio Tibagi (Paraná, Southern Brazil). Arch Hydrobiol 149:285-306.

Meeren TVD, Brunvold L, Sandaa L, Bergh AO, Castberg C, Thyrhaug R, Mangor-Jensen A (2011) Water quality and microbial community structure in juvenile Atlantic cod (Gadus morhua L.) cultures. Aquaculture 316:111-120.

Nelson JA, Whitmer ME, Johnson EA, Dubah D, Stewart DJ (1999) Wood-eating catfishes of the genus Panaque: gut microflora and cellulolytic enzyme activities. J Fish Biol 54:1069-1082.

Nelson JA (2002) Metabolism of three species of herbivorous loricariid catfishes: influence of size and diet. J Fish Biol 61:1586-1599.

Olafsen JA (2001) Interactions between fish larvae and bacteria in marine aquaculture. Aquaculture 200:223-247.

Podkowa D, Goniakowska-Witalinska L (2003) Morphology of the air-breathing stomach of the catfish Hypostomus plecostomus. J Morphol 257:147-163.

Prejs A, Blaszczyk M (2006) Relationship between food and cellulase activity in freshwaters fishes. J Fish Biol 11:447-442.

Ramirez RF, Dixon BA (2003) Enzyme production by obligate intestinal anaerobic bacteria isolated from oscars (Astronotus ocellatus), angelfish (Pterophyllum scalare) and southern flounder (Paralichthys lethostigma). Aquaculture 227:417-426.

Ringo E, Birkbeck TH (1999) Intestinal microflora of fish larvae and fry. Aquac Res 30:73-93.

Roeselers G, Mittge EK, Stephens WZ (2011) Evidence for a core gut microbiota in the zebrafish. ISME J 5:1595-1608.

Seeto GS, Veivers KD, Clements K, Staylor M (1996) Carbohydrate utilization by microbial symbionts in the marine her- bivorous fishes Odax cyanomelas and Crinodus lophodon. J Comp Physiol 165:571-579.

Shangong W, Gao T, Zheng Y, Wan W, Cheng Y, Wang G (2010) Microbial diversity of intestinal contents and mucus in Yellow catfish (Pelteobagrus fulvidraco). Aquaculture 303:1-7.

Shewan JM (1977) The bacteriology of fresh and spoiling fish and the biochemical changes induced by bacterial action. In: Sutcliffe P, Disney J (eds) Proceedings of the Conference on handling, proceeding and marketing of tropical fish. Tropical Products Institute, London, pp 51-56.

Shewan JM, Hobbs G, Hodgkiss W (1960) The Pseudomonas and Achromobacter groups of bacteria in the spoilage of marine white fish. J Appl Bacteriol 23:463-468.

Shiro I, Niki A, Sugita H (2006) Changes in microbial communities associated which the conditioning of filter material in recirculating aquaculture systems of the puffer fish Takifugu rubripes. Aquaculture 256:287-295.

Silva FCP, Brito MGF, Farias LM, Nicoli JR (2005) Composition and antagonistic activity of the indigenous intestinal microbiota of Prochilodus argenteus Agassiz. J Fish Biol 67:1686-1698.

Silva FCP, Nicoli JR, Zambonino-Infante JL, Le Gall ML, Kaushik S, Gatesoupe FG (2010) Influence of partial substitution of dietary fish meal on the activity of digestive enzymes in the intestinal brush border membrane of gilthead sea bream, Sparus aurata and goldfish, Carassius auratus. Aquaculture 306:233-237.

Silva FCP, Nicoli JR, Zambonino-Infante JL, Kaushik S, Gatesoupe FJ (2011) Influence of the diet on microbial diversity of fecal and gastrointestinal contents in gilthead sea bream (Sparus aurata) and intestinal contents in goldfish (Carassius auratus). Microbiol Ecol 78:285-296.

Smith LS (1989) Digestive functions in teleost fishes In: Halver JE (ed) Fish nutrition. Academic Press, San Diego, pp 331421.

Smith TB, Wahl DH, Mackie RI (1996) Volatile fatty acids and anaerobic fermentation in temperature piscivorous and omnivorous freshwater fish. J Fish Biol 48:829-841.

Soares MCS, Marinho MM, Huszar VHL, Branco CWC, Azevedo, S. (2008) The effects of water retention time and watershed features on the limnology of two tropical reservoirs in Brazil. Lakes Reserv Res Manage 13:257-269.

Sullan KE, Essingen SD, Lozupone A, O’Connor MP, Rosen GL, Knight B, Killian S, Russel J (2012) Environmental and ecological factors that shape the gut bacterial communities of fish: a meta-analysis. Mol Ecol 21:3363-3378.

Syvokiene J, Mickeniene S (1999) Micro-organisms in the digestive tract of fish as indicators of feeding condition and pollution. J Mar Sci 56:147-149.

Teixeira TP, Pinto, BCT, Terra BF, Estiliano EO, Gracia D, Araújo FG (2005) Diversidade das assembléias de peixes nas quatro unidades geográficas do rio Paraíba do Sul. Iheringia, Sér Zool 95:347-357.

Terra BF, Araújo FG (2011) A preliminary fish assemblage index for a transitional river reservoir system in southeastern Brazil. Ecol Indic 11:874-881.

Terra BF, Santos ABI, Araújo, FGA (2010) Fish assemblage in a dammed tropical river: an analysis along the longitudinal and temporal gradients from river to reservoir. Neotrop Ichthyol 8:599-606. 
Vaz MM, Toquarto VC, Barbosa NDC (2000) Guia Ilustrado de Peixes da Bacia do Rio Grande. CEMIG/CETEC, Belo Horizonte, 144 pp.

Wong S, Rawls JF (2012) Intestinal microbiota composition in fishes is influenced by host ecology and environment. Mol Ecol 21:3100-3102.

Wu S, Gao T, Zheng Y (2010) Microbial diversity of intestinal contents and mucus in yellow catfish (Pelteobagrus fulvidraco). Aquaculture 303:1-7.

Zambonino Filho E, Schulz UH (2003) Migratory fishes of the Uruguay river. In: Carolself J, Harvey B, Ross C, Baer A (eds) Migratory fishes of South America: Biology, Fisheries and Conservation Status. International Development Research Center, Ottawa, pp 157-194.

Zhao J, Shi B, Qing-ru J, Ke CH (2012) Changes in gut-associated flora and bacterial digestive enzymes during the development stages of abalone (Haliotis diversicolor). Aquaculture 341:147-153.

All the content of the journal, except where otherwise noted, is licensed under a Creative Commons License CC BY-NC. 